\title{
The effect of dietary lipids on lipolysis in rat adipose tissue
}

\author{
By P. W. LARKING AND E. R. NYE \\ Department of Medicine, University of Otago Medical School, \\ Dunedin, New Zealand
}

(Received 6 August 1974-Accepted ro October 1974)

\begin{abstract}
I. Rats were fed for 8 weeks on one of five diets differing in the amount of fatty acids $18: 1$, $18: 2$ and $18: 3$. Lipolysis, in vitro, of epididymal fat from fed and fasted rats was measured both basally and in the presence of noradrenaline with and without prostaglandin $E_{1}$.

2. Lipolysis was markedly influenced by the type of dietary fat. In particular, lipolysis in adipose tissue from rats given diets rich in the fatty acid 18:3 was higher than in the rats given diets containing $18: 2$.

3. Results showing the effects of fasting on adipose tissue lipolysis are also presented.

4. The results are discussed in relation to the known effects of unsaturated fats on hyperplasia and protein synthesis in adipose tissue and on the possible role of prostaglandins.
\end{abstract}

Changes in the fatty acid composition of diets affect the rate of lipolysis in rat epididymal fat when enzyme activity is estimated by the amount of glycerol released in vitro. When rats weighing $150-170 \mathrm{~g}$ were given one of two diets containing maize oil or lard $(200 \mathrm{~g} / \mathrm{kg} \mathrm{diet})$ for 2 weeks, the basal level of glycerol released/g wet weight of tissue from pieces of fat pad incubated in vitro was significantly less in the rats given the unsaturated maize oil than in those given lard (Pawar \& Tidwell, I968). Carreau, Loriette, Counis \& Ketevi (1972) found that, for rats given diets containing sunflower oil or lard $(200 \mathrm{~g} / \mathrm{kg}$ diet) for 3 weeks from weaning, the glycerol released/ $\mathrm{mg}$ protein from the fat pads incubated in vitro, when stimulated by noradrenaline $(5 \mu \mathrm{g} / \mathrm{ml})$ was significantly higher in the group given sunflower oil, contrary to the findings of Pawar \& Tidwell (1968).

Dietary lipids may influence the level of lipolysis in adipose tissue through the potent antilipolytic effect of prostaglandins $\mathrm{E}_{1}$ and $\mathrm{E}_{2}\left(\mathrm{PGE}_{1}\right.$ and $\left.\mathrm{PGE}_{2}\right)$, since the precursors of these compounds are the essential fatty acids (van Dorp, Beerthuis, Nugteren \& Vonkeman, 1964). Therefore, giving diets rich in linoleic acid might result in lower levels of adipose tissue lipolysis because of increased availability of prostaglandin precursors (Shaw \& Ramwell, 1968). We have attempted a further evaluation of the effect of dietary lipids on lipolysis in rat adipose tissue in vitro.

\section{MATERIALS AND METHODS}

Animals and diets. Sixty Wistar rats $7-9$ weeks old (average weight, $19 \circ \mathrm{g}$ ) were divided into five groups, each of twelve animals, and each group was fed ad lib. on one of five diets (see Table I) for 8 weeks.

Experimental procedures. At the end of this 8-week period, food was withdrawn from all the animals at 09.00 hours. Immediately, three animals from each group were 
Table I. Fat source and fatty acid composition of diets given to rats

\begin{tabular}{|c|c|c|c|c|c|}
\hline & \multicolumn{5}{|c|}{ Diet* } \\
\hline & A & B & C & D & $\mathbf{E}$ \\
\hline \multicolumn{6}{|l|}{ Dietary fat $(\mathrm{g} / \mathrm{kg})$ : } \\
\hline Linseed oil & 200 & 一 & - & - & - \\
\hline Sunflower oil & - & 200 & I 50 & 50 & - \\
\hline Beef fat & - & - & 50 & $15^{\circ}$ & 200 \\
\hline \multicolumn{6}{|c|}{ Principal fatty acids (percentage by weight): } \\
\hline $14: 0$ & $O \cdot I$ & 0.2 & r.o & $I \cdot 7$ & \\
\hline $16: 0$ & $7 \cdot 2$ & $8 \cdot 3$ & $9 \cdot 8$ & $20 \cdot 3$ & $24 \cdot 8$ \\
\hline $16: 1$ & $0 \cdot I$ & 0.2 & 0.9 & $2 \cdot 3$ & $2 \cdot 4$ \\
\hline I8:0 & $4 \cdot 5$ & $6 \cdot 0$ & II 3 & $17 \cdot 7$ & $23 \cdot 6$ \\
\hline I8:I & $17 \cdot 3$ & $29 \cdot 6$ & 34.5 & $36 \cdot 0$ & $38 \cdot 0$ \\
\hline $18: 2$ & $20 \cdot 3$ & $53 \cdot 3$ & $39^{\circ} 0$ & $13 \cdot 6$ & $I \cdot 8$ \\
\hline $18: 3$ & $50 \cdot 1$ & $\mathrm{I} \cdot 8$ & $I \cdot 2$ & $I \cdot I$ & 0.8 \\
\hline
\end{tabular}

* Each diet also contained $(\mathrm{g} / \mathrm{kg})$ : casein 250 , wheat bran 60 , mineral salt mix 40 , vitamin mix 20 and sucrose $43^{\circ}$.

taken, weighed and anaesthetized with sodium pentobarbitone ( $1 \mathrm{ml} / \mathrm{kg}$ body-weight). Blood samples were taken from the abdominal aorta, transferred to ice-cold heparinized tubes, centrifuged, and the plasma taken and stored at $-20^{\circ}$. The epididymal fat pads were removed and immersed in warm saline solution. Ten pieces of fat (each approximately $50 \mathrm{mg}$ ) from each rat were separately incubated at $37^{\circ}$ in $\mathrm{r} \cdot 2 \mathrm{ml}$ Krebs bicarbonate buffer $\left(\mathrm{pH}_{7} \cdot 4\right)$ containing albumin $(4 \circ \mathrm{g} / \mathrm{l})$ and glucose $(0 \cdot 54 \mathrm{mg} / \mathrm{l})$. The following five incubation mixtures were used and each incubation was done in duplicate: (I) no drugs, (2) noradrenaline $0.1 \mu \mathrm{g} / \mathrm{ml}$, (3) noradrenaline $0.2 \mu \mathrm{g} / \mathrm{ml}$, (4) noradrenaline $0.2 \mu \mathrm{g} / \mathrm{ml}$ and $\mathrm{PGE}_{1} 0.01 \mu \mathrm{g} / \mathrm{ml}$, and (5) noradrenaline $0.2 \mu \mathrm{g} / \mathrm{ml}$ and $\mathrm{PGE}_{1} \mathrm{O} \cdot \mathrm{I} \mu \mathrm{g} / \mathrm{ml}$. Thus on day $\mathrm{I}$, fifteen rats were killed (five diet groups, three rats/ group) and $r_{5} 0$ separate pieces of tissue incubated (ten pieces per rat). On day 2 ( $24 \mathrm{~h}$ fasting), day 3 ( $48 \mathrm{~h}$ fasting) and day 4 ( $72 \mathrm{~h}$ fasting) the procedure for day $\mathrm{I}$ was repeated.

Glycerol released into the incubation medium was determined by the method of Chernick (1969). The fatty acid composition of the diets and of adipose tissue triglycerides was determined using gas-liquid chromatography (Hunter, Buchanan \& Nye, 1970). Free fatty acids (FFA) in plasma were determined by the method of Laurell \& Tibbling (1967). The results were analysed statistically by an analysis of variance.

\section{RESULTS}

The mean weight of animals at the start of the in vitro experiments was $377 \mathrm{~g}$. Differences between the mean weights for rats in groups given different diets were not significant. The composition of the fatty acids in the diets and those of adipose tissue of rats given the diets for 8 weeks are shown in Tables I and 2. A summary of the analysis of variance of the results of in vitro incubation of adipose tissue is presented in Table 3. The differences between levels of lipolysis in tissues from fed and fasted animals and differences between rats fed on different diets was highly significant 
Table 2. Principal fatty acids (percentage by weight) in the epididymal fat pads of rats given diets containing different amounts of linseed oil, sunflower oil and beef fat for 8 weeks

(Mean values for duplicate determinations for three rats/group)

\begin{tabular}{crrrrr} 
& \multicolumn{5}{c}{ Dietary group* } \\
\cline { 2 - 6 } $\begin{array}{c}\text { Principal fatty acids } \\
\text { I6:0 }\end{array}$ & B & C & D & E \\
16:1 & 15 & 16 & 17 & 22 & 23 \\
$18: 0$ & 4 & 3 & 4 & 5 & 7 \\
$18: 1$ & 2 & 2 & 3 & 3 & 5 \\
$18: 2$ & 27 & 32 & 36 & 45 & 50 \\
$18: 3$ & 19 & 39 & 34 & 17 & 6 \\
& 29 & 2 & 0.5 & 0.8 & 0.7
\end{tabular}

* For details of diets, see Table I.

Table 3. Analysis of variance of the results (glycerol release) from the in vitro incubation* of adipose tissue from rats given diets containing different amounts of linseed oil, sunflower oil and beef fat for 8 weeks, then fasted for $0,24,48$ and $72 h$

\section{Source of variance}

Nutritional states $\nmid$

Dietst

Nutritional states $v$. diets

Between rats within (diet $v$. nutritional state)

Drugs§

Nutritional states $v$. drugs

Diets $v$. drugs

Nutritional states $v$. diets $v$. drugs

Rat within (diet $v$. nutritional state) $v$. drugs

Between duplicate measurements

\section{Degrees of \\ freedom}

3
4
12
40
4
12
16
48
160
300

Statistical significance of

Mean square interaction

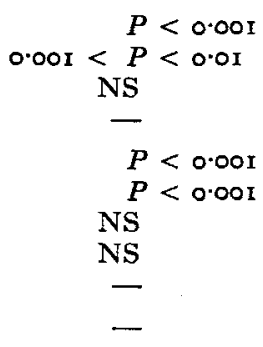

NS, not significant $(P>0.05)$.

* For details of incubation procedure, see p. 292.

+ Fasted for $0,24,48$ and $72 \mathrm{~h}$.

$\ddagger$ For details, see Table $I$.

$\S$ Noradrenaline and prostaglandin $\mathrm{E}_{1}$ included either together or alone and at different concentrations in the incubation mixture, see p. 292.

$(P<0.001$ and $0.01<P<0.001$ respectively (Table 4$)$ ). The effect of fasting on lipolysis was most noticeable after $72 \mathrm{~h}$ rather than after shorter periods of fasting. Further analysis of the differences between mean lipolysis rates for the various dietary groups by Scheffé's test (Scheffé, 1959) indicated that there were significant differences $(P<\mathrm{O} \cdot \mathrm{I})$ between group $\mathrm{A}$ (linseed oil) and groups $\mathrm{B}, \mathrm{C}$ and $\mathrm{D}$, in which all or part of the dietary fat was sunflower oil. The differences between $A$ and $C$, or $D$ were highly significant $(P<0.05)$. There was no significant difference between groups $\mathrm{A}$ and $\mathrm{E}$ or between $\mathrm{E}$ and $\mathrm{B}, \mathrm{C}$ or $\mathrm{D}$.

As expected, the differences between the effects of the various levels of drugs used were highly significant $(P<0.001)$ (Table 4$)$. There was also a highly significant 
Table 4. Average lipolysis rates ( $n$ mol/mg per $h$ ) for pieces of epididymal fat pads* from rats given diets containing different amounts of linseed oil, sunflower oil and beef fat for 8 weeks, then fasted for $0,24,48$ and $72 \mathrm{~h}$

(Mean values for duplicate determinations for three animals/group)

$\begin{array}{cccccc}\text { A } & \text { B } & \text { C } & \text { D } & \text { E } \\ \text { Lipolysis rate } & 3 \cdot 183 & 2.525 & 2.33 \text { I } & 2 \cdot 418 & 2.847\end{array}$

Analysis between dietary groups by Scheffé's (1959) test showed dietary group A to differ significantly from groups $\mathrm{B}, \mathrm{C}$ and $\mathrm{D}$. No other differences were significant (SEM 0.0154 ).

(b) Mean values for different nutritional states, drug combinations and their interactions

Drug combinations*

$\overbrace{\text { Noradrenaline } \mathrm{PGE}_{\mathbf{1}}}^{(\mu \mathrm{g} / \mathrm{ml})}$

0

$0 \cdot 1$

0.2

0.2

0.2

○

o

0

0.01

0.1

Mean values for nutritional states

\begin{tabular}{ccccc}
\multicolumn{3}{c}{ Period of fasting (h) } & Mean values for drug \\
0 & 24 & 48 & 72 & $\begin{array}{c}\text { M. } \\
\text { combinations }\end{array}$ \\
0.764 & $1 \cdot 232$ & $1 \cdot 054$ & $1 \cdot 327$ & $1 \cdot 095$ \\
$3 \cdot 179$ & $3 \cdot 353$ & $3 \cdot 206$ & $4 \cdot 52 \mathrm{I}$ & $3 \cdot 565$ \\
$4 \cdot 509$ & $4 \cdot 005$ & $4 \cdot 056$ & $5 \cdot 168$ & $4 \cdot 435$ \\
$2 \cdot 353$ & $2 \cdot 510$ & $2 \cdot 679$ & $3 \cdot 263$ & $2 \cdot 701$ \\
$1 \cdot 388$ & $1 \cdot 540$ & $1 \cdot 400$ & $1 \cdot 708$ & $1 \cdot 508$ \\
$2 \cdot 439$ & $2 \cdot 528$ & $2 \cdot 478$ & $3 \cdot 198$ &
\end{tabular}

The analysis of variance showed a highly significant nutritional state $v$. drug interaction and highly significant differences between drug combinations and between nutritional states (SEM for drugs 0.0077 , SEM for nutritional states $\left.0.013^{8}\right)$.

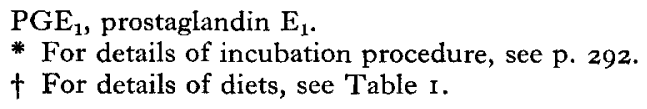

nutritional state $v$. drug interaction. The pattern of differences between nutritional states was generally similar for each drug and the interactions mainly reflect differences in the magnitude of the responses. The mean lipolysis rate in the presence of noradrenaline $+\mathrm{PGE}_{1}(0.2$ and $0 . \mathrm{I} \mu \mathrm{g} / \mathrm{ml}$ respectively), expressed as a percentage of that in the presence of $0.2 \mu \mathrm{g}$ noradrenaline $/ \mathrm{ml}$ is an indication of the changes in the effectiveness of $\mathrm{PGE}_{1}$ as an inhibitor of stimulated lipolysis, as the period of fasting increases. At $\circ \mathrm{h}$ of fasting, $\mathrm{PGE}_{1}$ reduced the lipolysis rate to $52 \%$ of the stimulated rate and at 24,48 and $72 \mathrm{~h}$, lipolysis was reduced to 63,66 and $63 \%$ respectively.

Differences between diets in the levels of plasma glycerol and FFA were not significant. However, plasma FFA levels for the four nutritional states differed significantly $(P<0.001$, Table 5$)$.

\section{DISCUSSION}

Plasma FFA and glycerol levels. The increased release of FFA from adipose tissue into the blood stream on fasting is mainly due to decreased esterification resulting from decreased glucose uptake into adipose tissue followed by increased rates of 
Table 5. The effect of fasting and diet on glycerol and free fatty acid (FFA) (nmol/l) in plasma from rats given diets containing different amounts of linseed oil, sunflower oil and beef fat for 8 weeks, then fasted for $0,24,48$ and $72 h$

(Mean values calculated from an analysis of variance)

\begin{tabular}{|c|c|c|c|c|c|c|}
\hline & & Period & ing (h) & & & \\
\hline & 0 & 24 & 48 & 72 & & SEM \\
\hline Glycerol & $0.18 \mathrm{I}$ & 0.170 & 0.182 & 0.177 & & 0.0082 \\
\hline FFA & 0.335 & 0.227 & 0.267 & 0.628 & & 0.0274 \\
\hline & & & tary gr & & & \\
\hline & A & $\mathbf{B}$ & $\mathrm{C}$ & $\mathrm{D}$ & $\mathbf{E}$ & \\
\hline Glycerol & 0.184 & $\rho \cdot 149$ & 0.188 & 0.188 & 0.179 & 0.009 \\
\hline FFA & 0.378 & 0.363 & 0.358 & $0.35^{2}$ & 0.369 & 0.031 \\
\hline
\end{tabular}

lipolysis as fasting continues (Scow \& Chernick, I970). Our results (Table 5) suggested that plasma FFA levels decreased during mild fasting, but increased markedly after 48-72 $\mathrm{h}$ of fasting. Basal rates of lipolysis, in vitro (Table $4 \mathrm{~b}$ ) were higher 24 and $48 \mathrm{~h}$ after fasting than at $\mathrm{oh}$, and were still increasing at $72 \mathrm{~h}$, when plasma FFA levels were also increasing.

The highly significant differences in vitro between different dietary treatments were not reflected in circulating plasma FFA or glycerol levels as there were no significant differences between dietary groups in these measurements. Another anomaly was associated with the lower levels of plasma triglycerides in animals given diets containing linseed oil compared to animals given diets containing saturated fats (Nye \& Larking, 1970); in the present experiment the highest levels of lipolysis in vitro were found in the animals given the diet containing linseed oil. Possibly lipolysis or re-esterification in adipose tissue in vivo may also be controlled by additional mechanisms that are affected by diet, or by increased removal of FFA.

Adipose tissue lipolysis in vitro. Our results were similar to those of Pawar \& Tidwell (1968). Rats given a diet rich in the fatty acid $18: 2$ (sunflower oil) had lower rates of lipolysis in vitro than those given beef fat, although the difference was not significant. However, when a diet rich in $18: 3$ (linseed oil) was given, the rates of lipolysis in adipose tissue were significantly higher than those for rats given diets containing sunflower oil. These differences are apparent both when lipolysis was stimulated by noradrenaline, and at the basal level. There were no significant diet $v$. drug or diet $v$. nutritional state interactions.

The effect of changes in fat-cell size and number with different dietary treatments has not been determined. It is known that giving weanling rats a diet rich in linoleic acid, compared to a diet containing lard, results in differences in adipocyte size and rates of incorporation of precursors into adipocyte RNA and DNA (Launay, Vodovar \& Raulin, 1968; Launay, Richard, Alavoine \& Raulin, 1972). Our animals were, however, 8-9 weeks old at the start of the experiment, a time when hyperplasia in the 
epididymal fat pad is almost complete and further growth occurs mainly by a process of cellular hypertrophy (Hubbard \& Matthew, I97I). The diets were therefore given when hyperplasia was probably of decreasing importance compared to hypertrophy and the effect on adipocyte number and size of a diet containing unsaturated fat might also have been of less significance. This suggestion was supported by the finding that the weights of rats for each dietary treatment after 8 weeks on the diet did not differ significantly. We have previously observed that giving a linseed-oil diet to rats from weaning for 13 months resulted in higher body-weights and epididymal-fat-pad weights compared to those of rats fed on mutton fat or hydrogenated coconut oil (Nye \& Larking, 1970). If diet had not affected adipocyte number, dietary unsaturated fats could possibly change the rates of RNA and DNA synthesis, thereby changing other metabolic processes. In comparative studies of the effects of dietary fat on size of adipocytes and protein synthesis in these cells, the fatty acid $18: 2$ has been used (Launay et al. 1968; Launay et al. 1972). Our experiments indicate the need for comparative studies in which $18: 3$ is included in the diet.

A feedback hypothesis relating increased lipolysis to increased synthesis of prostaglandin has been proposed (Shaw \& Ramwell, 1968). According to this hypothesis, diets which increase levels of prostaglandin precursors in adipose tissue should lower rates of lipolysis. Our results did not support a direct relationship, as lipolysis rates for rats given diets containing sunflower oil were not significantly lower than those for the rats fed on beef fat, which contains principally the fatty acid $18: 1$. With respect to the availability of prostaglandin precursors, all our diets should have contained adequate levels of linoleic acid, with the possible exception of diet $\mathrm{E}$.

The highest lipolysis rates were associated with the diet containing linseed oil and these may be accounted for by mechanisms suggested by other workers. There is competition by $18: 3$ for the enzymes involved in chain elongation and desaturation of $18: 2$ to $20: 3$ and $20: 4$ acids, the precursors of $\mathrm{PGE}_{1}$ and $\mathrm{PGE}_{2}$ (Brenner \& Peluffo, 1966). Also, prostaglandin synthesis is markedly inhibited by some unsaturated fatty acids, particularly $18: 3 \omega_{3}$ (Pace-Asciak \& Wolfe, 1968). Some of the increased lipolysis rates found in our rats fed on linseed oil may, therefore, result from these mechanisms. Further investigations comparing the effects of giving $18: 3 \omega 6$ (a precursor of $8,11, I_{4}, 20: 3$ and 5, 8, II, 14, 20:4 and thus of $\mathrm{PGE}_{1}$ and $\mathrm{PGE}_{2}$ ) and $18: 3 \omega_{3}$ on lipolysis would now seem appropriate.

The effect of fasting on the antilipolytic effect of $P G E_{1}$. While $\mathrm{PGE}_{1}$ is a potent inhibitor of lipolysis in vitro in adipose tissue from fed rats, under certain experimental conditions minimal inhibition is found when adipose tissue from $24 \mathrm{~h}$ fasted animals is incubated (Carlson \& Micheli, I970). The results indicate that the effectiveness of $\mathrm{PGE}_{1}$ is decreased during fasting, although a considerable antilipolytic effect on stimulated lipolysis is still present. This in part accounts for the highly significant nutritional state $v$. drug interaction. Carlson \& Micheli (1970) showed that injection of glucose into the fasted rat $\mathrm{x} h$ before removal of the fat pads for incubation, restored the antilipolytic effect of $\mathrm{PGE}_{1}$ on basal lipolysis rates. Therefore, the decreased effectiveness of added $\mathrm{PGE}_{1}$ may be due to the increased synthesis within the adipocyte resulting from an increased supply of fatty-acid pre- 
cursors derived from decreased re-esterification and increased lipolysis during fasting. The increased supply of prostaglandin within the adipocyte would then reduce the effect of any additional prostaglandin. Alternatively, the increased amounts of FFA having a prostaglandin-like configuration found during fasting may block some prostaglandin receptor sites.

The authors thank Dr J. E. Pike of the Upjohn Company for the gift of PGE 1 and Mr G. F. S. Spears of the Department of Social and Preventive Medicine, University of Otago Medical School for the statistical analysis. This work was supported by the Medical Research Council of New Zealand.

\section{REFERENCES}

Brenner, R. R. \& Peluffo, R. O. (1966). F. biol. Chem. 24r, 52 I 3.

Carlson, L. A. \& Micheli, H. (1970). Acta physiol. scand. 80, 289.

Carreau, J. P., Loriette, C., Counis, R. \& Ketevi, P. (1972). Biochim. biophys. Acta 280, 440.

Chernick, S. S. (1969). Meth. Enzym. 14, 628.

Hubbard, R. W. \& Matthew, W. T. (r97I). F. Lipid Res. 12, 286.

Hunter, J. D., Buchanan, H. \& Nye, E. R. (1970). F. Lipid Res. I1, 259.

Launay, M., Richard, M., Alavoine, R. \& Raulin, J. (1972). Nutr. Rep. Int. 5, 339.

Launay, M., Vodovar, N. \& Raulin, J. (1968). Bull. Soc. Chim. biol. 50, 439.

Laurell, S. \& Tibbling, G. (1967). Clinica chim. Acta 16, 57.

Nye, E. R. \& Larking, P. W. (1970). Gerontologia 16, 266.

Pace-Asciak, C. \& Wolfe, L. S. (1968). Biochim. biophys. Acta 152, 784 .

Pawar, S. S. \& Tidwell, H. C. (1968). Biochim. biophys. Acta 164, I67.

Scheffé, H. (1959). The Analysis of Variance. New York: Wiley.

Scow, R. O. \& Chernick, S. S. (1970). In Comprehensive Biochemistry Vol. 18, p. 23 [M. Florkin and E. H. Stotz, editors]. Amsterdam: Elsevier.

Shaw, J. E. \& Ramwell, P. W. (I968). F. biol. Chem. 243, I498.

van Dorp, D. A., Beerthuis, R. K., Nugteren, D. H. \& Vonkeman, H. (r964). Biochim. biophys. Acta 9o, 204 . 